\title{
The politics of researching global health politics \\ Comment on "Knowledge, moral claims and the exercise of power in global health"
}

\section{Simon Rushton*}

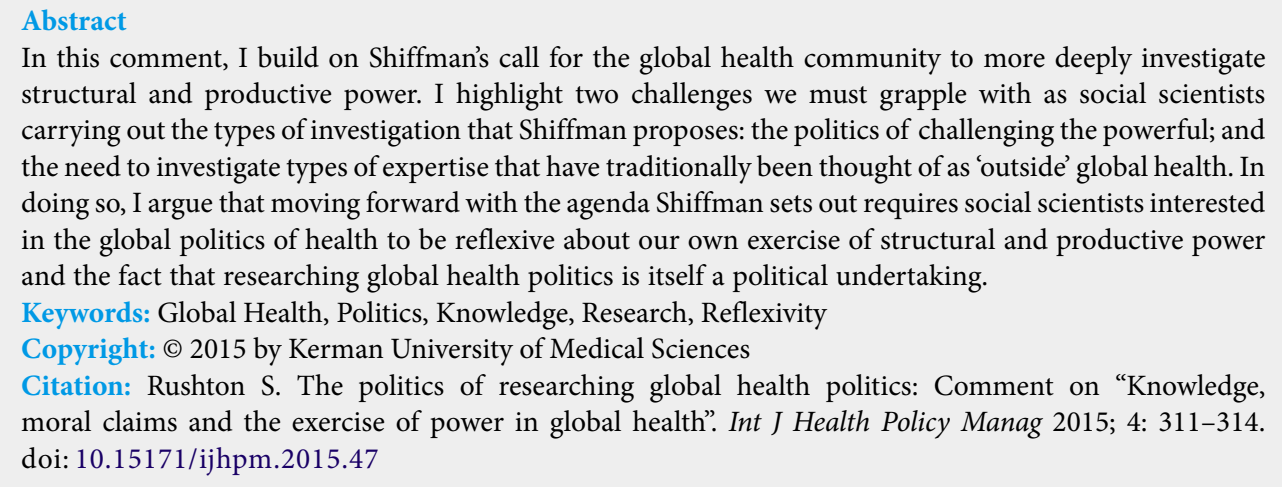

In this comment, I build on Shiffman's call for the global health community to more deeply investigate structural and productive power. I highlight two challenges we must grapple with as social scientists carrying out the types of investigation that Shiffman proposes: the politics of challenging the powerful; and the need to investigate types of expertise that have traditionally been thought of as 'outside' global health. In doing so, I argue that moving forward with the agenda Shiffman sets out requires social scientists interested in the global politics of health to be reflexive about our own exercise of structural and productive power and the fact that researching global health politics is itself a political undertaking.

Keywords: Global Health, Politics, Knowledge, Research, Reflexivity

Copyright: @ 2015 by Kerman University of Medical Sciences

Citation: Rushton S. The politics of researching global health politics: Comment on "Knowledge, moral claims and the exercise of power in global health". Int J Health Policy Manag 2015; 4: 311-314. doi: $10.15171 /$ ijhpm. 2015.47

\section{Article History:} Received: 1 February 2015 Accepted: 2 March 2015 ePublished: 4 March 2015
*Correspondence to:

Simon Rushton

Email: simon.rushton@sheffield.ac.uk

\section{Introduction}

Jeremy Shiffman's recent editorial, 'Knowledge, moral claims and the exercise of power in global health' (1), raised some important and often-overlooked issues. In particular, Shiffman sought to draw the attention of the global health community to the fact that the exercise of 'compulsory' power (where, by virtue of their material or financial resources, one actor can compel another to do something) is not the only form of power at work in global health. He argued that we need to also be alert to the exercise of 'structural' and 'productive' forms of power. Shiffman illustrates these forms by example:

"In global health we see structural power at work in the existence of a cadre of individuals - medical professionals, development economists, advocacy experts and others who offer advice to governments of low-income countries presumed to be in need of their input. And we see productive power at work as they create concepts for thinking about health priority-setting, such as the burden of disease, treatment cost-effectiveness and the right to receive care". These structural and productive forms of power, often rooted in actors' claims to expertise and moral authority, are, for Shiffman, important for understanding how decisions are made and how agendas are set within global health [themes on which Shiffman has made some important previous contributions (2,3)]. I concur wholeheartedly with his analysis, and with his conclusion that we ought to interrogate the origins and uses of both of these forms of power. In this short comment I build on Shiffman's editorial, highlighting two challenges we must grapple with as social scientists in carrying out the types of investigation into power that he proposes.

First, picking up on Shiffman's injunction to "investigate how epistemic and normative power get exercised in the global health field", I raise some questions around the politics of challenging the powerful. How can we begin to define what are (and what are not) legitimate forms of power in global health? Having done so, how do we approach the politically difficult issue of challenging well-intentioned global health actors whose exercise of power we believe to be illegitimate? And, as researchers, how can we do so in a way which is reflexive about our own positionality vis a vis the issues we study - including the solidity of our own claims to expertise and moral authority?

Second, in examining the exercise of structural and productive power in 'global health', how should we define the boundaries of relevant knowledge and expertise? Here I seek to place global health in a broader context, highlighting the fact that we need to pay attention not only to structural and productive power 'within' what we traditionally see as the global health sphere, but also the influence that these forms of power from 'outside' have in determining global health outcomes. In particular, I argue that non-health forms of expertise have become increasingly influential, with individuals from management consultancy and economics - not just from medicine and public health - exercising real power in ways that are too seldom scrutinized.

\section{The politics of challenging the powerful}

Tony Benn, the recently deceased stalwart of left-wing Labour politics in the UK, famously said that we should ask powerful people five questions: "what power do you have; where did you get it; in whose interests do you exercise it; to whom are you accountable; and, how can we get rid of you?" Benn went on to warn that "Anyone who cannot answer the last of those questions does not live in a democratic system" (4).

Nobody would, I assume, try to argue that the 'system' of 
global health (if such a thing even exists) is in any way democratic. Yet there is (again, I assume) a generally shared view that the system should strive for at least some degree of legitimacy - for example that it should incorporate effective accountability mechanisms, and that it should operate in the interests of those whom it is intended to serve. How we define 'in the interests of those whom it is intended to serve' is a deeply political question, going to the heart of the moral claims through which exercises of power are often justified. As Shiffman points out, 'humanitarian motives' are often claimed by those operating in the field of global health, although we know that there is a much more complex variety of motives in play - including such interests as profit and national security.

That issue aside, it is worth thinking through the politics of challenging the (perhaps well-intentioned) powerful, considering what we seek to achieve in doing so, and being cognizant of our own position as global health researchers/ advocates. To be clear: I am not arguing that we should shrink from pursuing the kind of critical analyses that Shiffman suggests. In fact I would argue the reverse - that as researchers interested in the global politics of health it is incumbent on us to undertake them. What I am saying is that our own actions in pursuing this agenda are themselves highly political, and can lead to another set of political, moral and ethical choices. We need, therefore, to proceed in a way which builds in an element of reflexivity about the basis of our own judgments, and also about the ways in which our research impacts upon the object of our study (5).

As social scientists we are aware of the challenges posed by our own positionality vis-à-vis the issues we research. We bring our own personal and disciplinary baggage, our own biases and preconceptions. We cannot lay claim to an objective 'view from nowhere' (6). Often we might find our views and assumptions shared by others in the same field. It would not, for example, be a surprise to find a gathering of global health scholars sharing similar ideas about the merits or otherwise of Big Tobacco on the one hand, and Médecins sans Frontières on the other. But perhaps more frequently we will discover differences of opinion - as indeed we find in scholarly debates over the roles played by the World Bank or Big Pharma in global health.

Shiffman rightly exhorts us to challenge our assumptions about which actors exercise power legitimately and which do not, and to more fully investigate the origins and uses of power by the whole range of global health actors. That way lies a more nuanced account both of those actors themselves, and also of the global health 'system' as a whole. But on what basis can we judge legitimacy in a system which has none of the accoutrements of democracy? Is it the case that our judgment would merely reproduce our pre-existing political convictions about what forms of power are and are not legitimate? If so, how can we adjudicate between opposing positions in the debate?

There is another political question for us to answer too: what should we do if we find (or believe we find) the illegitimate exercise of power?

To illustrate (although not to satisfactorily answer) these questions, let us take an example - a deliberately hard case.

There seems to be general agreement that the Bill \& Melinda
Gates Foundation has become an enormously powerful actor in global health (7-9). In part, of course, the Foundation's power comes from the size of its financial resources: spending over 3.5 billion US dollars each year across all of its programs (10) makes it by any measure a top-tier global health donor. Through the allocation of those resources the Foundation has the ability to effectively create a priority around those health issues it chooses to focus upon. Its significance as a global health donor also means that it gets a seat at many of the tables at which key decisions are made (the 'Foundation seat' on the boards of GAVI and the Global Fund, for example, has most often been filled by the Gates Foundation) and an entry to high-level global discussions. To take one example, in 2011 Bill Gates was commissioned by French President Nicolas Sarkozy to write a report for the leaders of the G8 on Innovation with Impact: Financing 21st Century Development (11).

It would be too simplistic, however, to assume that this influence is solely a product of the Foundation's financial might. It also lays claim to a depth of expertise on global health and development issues, and also to moral authority. Indeed Gates' decision (like that of Warren Buffet) to devote a substantial proportion of his personal fortune to tackling global health crises could be seen as the ultimate humanitarian gesture.

Do these epistemic and normative claims render the Gates Foundation's exercise of power legitimate? I would not expect to find agreement over that question: it would depend on the legitimacy criteria that we apply - which in turn is intimately related to our own political positions. For some 'input legitimacy' (which rests upon the participatory processes through which decisions are made) is crucial. As someone committed to the fundamental importance of democratizing decision-making, and with a deep suspicion of the power exercised by the super-rich, I would myself be in this camp. (I realize, of course, that it would be difficult on that basis to argue for the legitimacy of any transnational actors). I am aware, however, that others would argue on the basis of 'output legitimacy' (the effectiveness of an institution's actions in solving the problems it aims to address) that the Gates Foundation does operate legitimately. These two approaches, both rooted in a particular set of political ideas, lead to diametrically opposed views of the legitimacy of the Foundation's exercise of power.

My point here is categorically not that we should avoid discussing the legitimacy of the Gates Foundation (or any other global health actor), but rather that we should recognize that this is a political discussion and that our own positions in that argument are inherently political. We should not attempt to take cover behind some bogus claim to 'objectivity' or 'neutrality'.

Furthermore, supposing we did find that the Gates Foundation exercises power in an illegitimate manner, what would we want to do about it? Would we want to drive Gates (and his money) out of global health? Would we want to try to find some way to make the Foundation more accountable? Or should we just grit our teeth and get on with it, accepting some illegitimacy in the system for the greater good of the issues we care so much about? How should we decide which of these courses of action is 'best' for global health? And, importantly, what would be our own claim to legitimacy in 
choosing between those options?

\section{Global health and 'outside' expertise}

Having grappled with those challenges, how do we determine which actors (and, by extension, what kinds of knowledge) to investigate? It is striking that in his discussion of expertise and power, Shiffman's examples are all traditional forms of health knowledge. He tells us that "actors may claim expertise concerning the biomedical causes of a condition, its prevalence, broader determinants of health, appropriate policy responses, or interventions needed to address or avert illness".

I would not disagree with any of those examples, but the list risks creating the impression that only a specific form of expertise - 'health expertise' - confers power on actors in global health. Contrary to this, it seems clear that other forms of 'outside' expertise have become increasingly influential in global health over the past two decades - not least by virtue of the global reach of neoliberal ideology (12). Interestingly, this has not been the result of an externally-driven 'hostile takeover' of global health - quite the reverse: it has often been the result of global health actors consciously seeking to bring in new forms of knowledge and expertise which are thought to offer new approaches (and, in productive power terms, new concepts and categorizations).

One example of this phenomenon is what we might call the 'McKinsey-ization' of global health. As in many other sectors (and as seen at both the national and international levels), a high premium has come to be placed on the skills and expertise of management consultants. Thus McKinsey \& Co. (and some of its competitors) have come to have a significant say in how things are done in global health. In part this has been a product of the very close relationship that McKinsey in particular has with the Gates Foundation $(13,14)$, but other global health institutions have also turned to the same firms for expert input. Their influence goes far beyond what we might think of as merely 'technocratic' functions (monitoring and evaluation of interventions, for example), to include much more strategic (and, I would argue, much more political) tasks. Consultants from McKinsey, for example, played key roles in the initial design of the Global Fund [Rajat Gupta of McKinsey went on to be one of the two private sector representatives on the first Global Fund Board (15)], as well as in the formulation of the Gates Foundation's global health strategies. Most people working in the global health field will have observed the number of former management consultants (from McKinsey and other firms) now occupying senior posts in major international health institutions. Unsurprisingly, these individuals bring with them particular skills, knowledge, and forms of expertise. Crucially, these 'non-health' forms of productive power have given them the ability to shape the global governance of health in significant ways.

A second example would be the extent to which global health institutions have valued the expertise of mainstream economists, and not just health economists. Jeffrey Sachs is probably the most prominent - and indeed one of the most influential of all contemporary voices in global health and development. Sachs' personal website trumpets the impact he has had:

"Since the adoption of the Millennium Development Goals
(MDGs) in 2000, Professor Sachs has been the leading academic scholar and practitioner on the MDGs. He chaired the WHO Commission on Macroeconomics and Health (2000-1), which played a pivotal role in scaling up the financing of health care and disease control in the low-income countries to support MDGs 4, 5, and 6. He worked with UN Secretary-General Kofi Annan in 2000-1 to design and launch the Global Fund to Fight AIDS, TB, and Malaria. He worked closely with senior officials of the administration of George W. Bush to develop the PEPFAR program to fight HIV/AIDS, and the PMI to fight malaria. On behalf of Secretary-General Kofi Annan, from 20022006 he chaired the UN Millennium Project, which was tasked with developing a concrete action plan to achieve the MDGs" (16).

An economist, not someone with expertise in medicine, public health, epidemiology, virology, or any of the other traditional forms of 'health knowledge', Sachs' position at the heart of many of the key global health decision-making processes perfectly demonstrates the extent to which 'outside' expertise can confer power and influence in the global health system - and this has not been despite the fact that it is an 'outside' form of expertise, but precisely because of that fact. The lesson for global health researchers is clear: that we need to cast our net widely in defining 'global health actors', and that we need to be similarly broad in our understanding of what types of knowledge and expertise matter in global health and alert to the ways in which some types of knowledge may come to have power over others. As Shiffman points out, privileging certain kinds of knowledge can confer power on particular types of individuals, creating a 'chicken and egg' problem of determining which comes first: do the experts legitimate the knowledge, or vice versa?

\section{Conclusion}

Shiffman's call on the global health research community to make more effort to investigate the origins and legitimacy of structural and productive power is important and welltimed. However, I have argued here that taking up this agenda challenges us in at least two ways.

First, it requires us to be explicit about the political nature of our analyses and reflexive about our own scholarly activity. Researchers in global health politics, just as in any other social science field, cannot avoid bringing a wealth (or a burden) of preconceptions, prejudices, and political commitments with them. Whilst social scientists know this in theory, we are often guilty of failing to address it in practice. We (and I include myself in this criticism) often fall into the trap of presenting our arguments as objective truths. Our disciplines themselves are often just as elitist, hierarchical and non-transparent as the global health institutions we seek to criticize. Researching global health politics, not least when we seek to challenge the powerful, is itself a political activity. We should embrace that, not shy away from it.

Second, Shiffman's call challenges us to be broad in our vision of 'global health' as a field. We need to be alert to the power of actors and ideas from outside the traditional health field, and to better understand how, why, and with what effects particular forms of expertise come to be valued in global health politics. Ultimately, global health governance is not 
an island. It exists in the broader context of a global political economy characterized by various kinds of structural and productive (not to mention coercive) power. In researching how global health priorities and strategies are determined we always need to make sure that we do not lose sight of this important fact.

\section{Acknowledgments}

I am grateful to Jeremy Shiffman, Sophie Harman, and the two anonymous IJHPM reviewers for their helpful comments on a previous draft of this paper.

\section{Ethical issues}

Not applicable.

\section{Competing interests}

Author declares that he has no competing interests.

\section{Author's contribution}

$\mathrm{SR}$ is the single author of the manuscript.

\section{Endnotes}

In addition, those who argue for the legitimacy of the Gates Foundation often make arguments such as the fact that the Foundation is accountable under U.S. Foundation law, and that it exercises a relatively high degree of transparency.

\section{References}

1. Shiffman J. Knowledge, moral claims and the exercise of power in global health. Int J Health Policy Manag 2014; 3: 297-9. doi: 10.15171/ijhpm.2014.120

2. Shiffman J. A social explanation for the rise and fall of global health issues. Bull World Health Organ 2009; 87: 608-13. doi: 10.2471/blt.08.060749

3. Shiffman J, Smith S. Generation of political priority for global health initiatives: a framework and case study of maternal mortality. Lancet 2007; 370: 1370-9. doi: 10.1016/s01406736(07)61579-7
4. New Statesman. Tony Benn (1925-2014): ten of his greatest quotes. 14 March 2014 [cited 29 January 2015]. Available from: http://www.newstatesman.com/politics/2014/03/tony-benn1925-2014-ten-his-greatest-quotes

5. Finlay L, Gough B. Reflexivity: A Practical Guide for Researchers in Health and Social Sciences. Oxford: Blackwell; 2003.

6. Nagel T. The View from Nowhere. Oxford: OUP; 1989.

7. Youde J. The Rockefeller and Gates Foundations in Global Health Governance. Global Society 2013; 27: 139-58. doi: 10.1080/13600826.2012.762341

8. McCoy D, McGoey L. Global Health and the Gates Foundation In Perspective. In: Rushton S, Williams OD, editors. Partnerships and Foundations in Global Health Governance. Basingstoke: Palgrave Macmillan; 2011.

9. Global Health Watch 2: An Alternative World Health Report. London: Zed Books; 2008.

10. \$3.6 billion in 2013 [internet]. Available from: http://www. gatesfoundation.org/who-we-are/general-information/foundationfactsheet

11. Gates B. Innovation with Impact: Financing 21st Century Development [internet]. November 3, 2011 [cited 3 March 2015]. Available from: http://www.gatesnotes.com/Development/G20Report-Innovation-with-Impact

12. Rushton S, Williams OD. Frames, Paradigms and Power: Global Health Policy-Making under Neoliberalism. Global Society 2012; 26: 147-67. doi: 10.1080/13600826.2012.656266

13. Buse K, Lee K. Business and Global Health Governance. LSHTM/WHO Discussion Paper 5. December 2005 [cited 29 January 2015]. Available from: http://www.odi.org/sites/odi.org. uk/files/odi-assets/publications-opinion-files/1997.pdf

14. McCoy D, Kembhavi G, Patel J, Luinte A. The Bill \& Melinda Gates Foundation's grant-making programme for global health. Lancet 2009; 373: 1645-53. doi: 10.1016/s0140-6736(09)605717

15. Ramsa S. Global Fund makes historic first round of payments. Lancet 2002; 359: 1581-2. doi: 10.1016/s0140-6736(02)08531-8

16. Full Bio about Jeffrey D. Sachs [internet]. [cited 29 January 2015]. Available from: http://jeffsachs.org/about/ 